\title{
Farmers' new strategy: myth or reality
}

\begin{abstract}
A. R. Sharma ${ }^{1}$
This paper examines the existence of a 'new strategy' supposedly adopted by the farmers under the rapid socio-economic transformation of rural societies in Nepal. While assessing the validity of the forecast regarding the reduction of pressure on the forests under a changed socio-economic context, the study categorically rejects the adoption of new strategy by the farmers and the rosy depiction regarding the forests. The study which was conducted in forty-two households of Badikhel Village Development Committee, Lalitpur, has found that, in villages, the labour relations are culturally determined, and the predominance of cereal cropping, the income source and other factors determine the purchase of agricultural inputs, mostly fertilisers, etc. The study recommends a subsistence oriented community forest policies in Nepal.
\end{abstract}

Keywords: Marketing, community forestry, socio-economy

M arketing has so far remained an ignored dimension of community forestry in Nepal. The Government is blamed for neglecting the commercial aspects of community forestry (Malla, 1993). This criticism stems from the fact that the rural people are increasingly engaged in off-farm cash earning activities (APROSC, 1980; Banskota, 1989). Yet, such aspects are not recognised in the community forestry policies (Malla, 1993). The latter focuses largely on meeting the rural peoples' subsistence needs for fodder, firewood, and timber (Anonymous, 1988; Manandhar, 1980). It is argued that the rural agrarian societies in Nepal, are rapidly transforming under marketing influences. The close subsistence economy is thus changed to an open market economy. Despite agriculture modernisation, farm incomes barely meet the subsistence needs. So new strategies are pursued by the farmers that include:

1) Off-farm employment,

2) Growing cash crops to support purchase of fertiliser,

3) Reducing either number or type of animals

4) Abandoning cultivation of crops that demand high labour inputs

5) Leaving marginal land uncultivated

6) Sending children to school, etc.

Thus marketing influence has resulted into:

- A reduction in the number of livestock accompanied by a decrease in the demand of fodder and leaf litter.

- An increase in firewood and timber demand due to the increasing number of commercial enterprises using these products.

It is rosily depicted that the pressure from the community forest may reduce in future. The reasons being the farmers' decision to involve themselves in various off-farm cash earning activities, not to cultivate some of their marginal lands, to reduce livestock population and adopt stall-feeding, and to grow trees in the private land. The crux of those arguments is while community forestry is oriented towards meeting the subsistence need, the rural people have moved away from such an economy. Hence, the strong urge is "rural people are interested in income that may be earned through off-farm employment, so community forestry should heed to this change and accept commercialisation" (Malla, 1993).

\section{Methodology}

\section{Study set-up and technique}

The study area comprises of 112 households located at Ward No. 3 and 4 of Badikhel Village Development Committee (VDC) of Lalitpur District. The Paharis, a Tibeto-Burmese group is the main inhabitants followed by the BrahminsIndo-Aryan group. A household survey was administered in forty-two households stratified into two wealth-classes. The household survey questionnaire covered mainly on the practice of voluntary exchange of labour (Parma), purchase of chemical fertiliser, etc. After pre-testing, the questionnaire was designed in MS Access database form. The survey information was probed at prima facie using MS Access software and was later analysed by SPSS, mainly Chi-square tests. Pearson's

\footnotetext{
${ }^{1}$ Department of Forest, Kathmandu
} 
Banko Janakari, Vol. 9, No. 2

Chi-square test was employed mainly to determine the significance of the differences but the validation rule often required other tests such as the Fisher's exact test.

\section{Observations}

"New strategy" : myth or reality

The study area is undergoing a rapid socio-economic transformation due to a strong market influence. The following are the major observations that cast doubt over the existence of the 'new strategy':

1) Off-farm employment: The out-migration of people, due to the off-farm employment opportunities elsewhere, is rather rare. Self- employment through Betbans (Bamboo-saddler) work, is pursued even by the male members, and therefore contributes substantially to the farm- household income. However, the market alone does not control the adaptation of such works by the households. The Brabmin households differ significantly from the Paharis in self-employment,
Sharma

mainly in the Betbans works.

2) Growing cash crop: Only one household in the study area, was found growing grapes for sell. No other cases of growing cash crops in substantial quantities were reported. However, fruit trees, mainly Choerospondias axillaris are being increasingly planted for cash income. The cereal crops are being still cultivated widely.

3) Reducing number or type of animal: A study at Ghusel on rural transformation from a subsistence to a cash economy reported on the increased pressure on ecosystem for increased supply of fodder and firewood (Bhatt et al., 1994). However, such a trend did not exist in the study area. Only one household was reported raising livestock in larger numbers for cash income. The Brahmins kept cows for subsistence consumption of milk. The rich households, generally keep cows but the poor households mostly the Paharis keep goats. Hence, the caste has a bearing on livestock-type being raised, though statistically not significant, than merely the market signals.

Table 1: Purchasing of chemical fertiliser using various sources of income (Pearson's chi-square value in paranthesis)

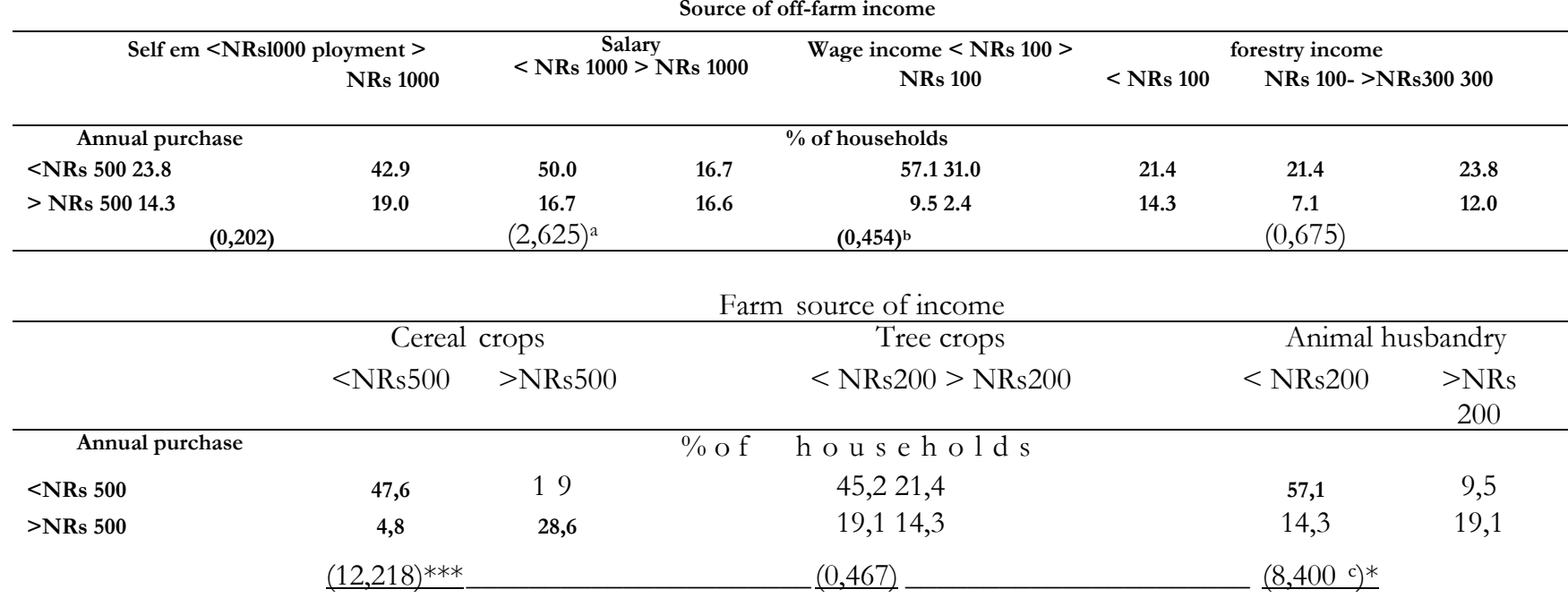

a. Fishers exact test; two tailed significance $=0,165$; b. Fisher's exact test; two tailed significance $=0,650$; c. Fisher's exact test: two tailed significance $=0,009$; significance level $*<0.05 * *<0.01 * * *<0.001$

Table 2: Purchase of chemical fertiliser from total monthly income, wealth class, caste, literacy and land resource perspectives (Pearson's chi-square value within brackets)

\begin{tabular}{|c|c|c|c|c|c|c|c|c|c|c|c|c|}
\hline \multirow{2}{*}{\multicolumn{3}{|c|}{ Monthly income (NRs) }} & \multirow{2}{*}{\multicolumn{2}{|c|}{ Wealth }} & \multirow{2}{*}{\multicolumn{2}{|c|}{ Caste }} & \multirow{2}{*}{\multicolumn{2}{|c|}{$\begin{array}{c}\text { Literacy } \\
\text { (Literate) }\end{array}$}} & \multicolumn{4}{|c|}{ Land resources } \\
\hline & & & & & & & & & & Khet & Bari & (ropani) \\
\hline & $<5000$ & $>5000$ & Rich & Poor & $\begin{array}{l}\text { No } \\
\text { Pahari }\end{array}$ & Pahari & $<2$ & $>2$ & yes & no & $<4$ & $>4$ \\
\hline \multicolumn{3}{|c|}{ Annual purchase } & & & & $\%$ & \multicolumn{6}{|c|}{ f households $\ldots \ldots \ldots$} \\
\hline$<$ NRs 500 & 52.4 & 14.3 & 21.4 & 42.5 & 19.1 & 45.2 & 42.9 & 23.8 & 33.3 & 33.3 & 52.4 & 14.3 \\
\hline \multirow{3}{*}{$\begin{array}{r}>\text { NRs } 500 \\
\text { missing }\end{array}$} & 11.9 & 21.4 & 28.6 & 4.8 & 21.4 & 14.3 & 4.8 & 28.5 & 33.4 & 0 & 16.7 & 16.6 \\
\hline & & & & 2.4 & & & & & & & & \\
\hline & \multicolumn{2}{|c|}{$(7.467) * *$} & $(10$ & 4)*** & \multicolumn{2}{|c|}{$(3.385 a)$} & \multicolumn{2}{|c|}{$-(9.355) * *$} & \multicolumn{2}{|c|}{$(10.714 \mathrm{~b})^{* *}$} & \multicolumn{2}{|c|}{$(3.565 c)$} \\
\hline
\end{tabular}




\section{Sharma}

5) Cash income to purchase chemical fertilisers:

The availability of cash definitely encourages investmen in chemical fertilisers. However, cash scarcity alone cannot be a determinant of application of organic manure in fields, which is rather highly influenced by the cultural factors. The cash income from all the sources is not equally spent on purchasing chemical fertilisers (Table 1). The households getting substantial incomes from off farm sources such as self-employment, wage income and community forest income, do not invest much in chemical fertilisers. The non-farm income from salary may be used but is insignificant on the chi- tests.

Only the households having income mainly from farm sources such as the cereals and animal husbandry, significantly invest in purchasing the chemical fertiliser. However, the households with a substantial farm income from the tree crops do not purchase it much. Therefore, the assumption that under the marketing influence, use of chemical fertiliser increases and pressure on forest decreases, may not be true. The use of fertiliser and organic manure in fields may also have another dimension, for that reason Table- 2 presents the purchase of chemical fertiliser from wealth, caste and literacy perspectives. The rich and more literate households significantly purchase more fertiliser than the poor and less literate households. (The operational definition of literacy is the number of household members having one time access to the formal education.) The Pahari households purchase less chemical fertilisers than the rest, though not in a significant extent. The increased income accruing from self-employment, salary and wage, is not significantly related with the increased purchase of chemical fertiliser, rather it is related to the farm income, wealth class and literacy. Furthermore, the households owning Khet (low land crop field) invest

Table 3: The practice of Parma by wealth and caste
Banko Janakari, Vol. 9, No. 2

significantly more cash in purchasing chemical fertiliser than those who do not own Kbet. However, having more Bari is not significantly related with the investment on chemical fertiliser on Fisher's exact test (see Table- 2).

4) Abandoning cultivation of crops that demand high labour inputs: The institutionalisation of voluntary exchange of labour such as Parma, Nogar, etc. is still evident in many parts of Nepal. The Parma is similar to a form of traditional work party or mwethya reported from Machakos District of Kenya, by which a person is called in neighbourhood to help with a special project, such as building a hut (Mortimore et al.y 1995). These indigenous institutions are as much efficient as the government sponsored co-operatives (Messer- schmidt, 1981). Parma and similar arrangement do not incur any direct cash to the employing household. The rich households having substantial cash income are still found abiding by the Parma (see Table- 3). Furthermore, if an institution like Parma is manifested in an area lying so close to the urban Kathmandu, the assumption that the farmers are abandoning cultivation of crops that demand high labour input, is rather difficult to accept. ing marginal land uncultivated: population growth is the cause of agriculture change, not the result, and that the principle change is the intensification of land use (Boserup, 1965), then the marketing influence should intensify the cultivation resulting into an intensive land use. This idea is traced back to the work of J. H. Thunen, who argues that the intensity of land use diminished away from a market centre (Hall, 1966). It is noted that farmers in the study area are practising multiple cropping of maize with soya bean. They have further intensified land use by planting Chorespondias axillaris on field boundary. $\%$ of households

\begin{tabular}{|c|c|c|c|c|}
\hline \multirow[t]{2}{*}{ Fuel for cooking } & \multicolumn{2}{|c|}{ Wealth class } & \multicolumn{2}{|c|}{ Caste } \\
\hline & Rich & Poor & Brahmin & \\
\hline Yes & 31 & 26.2 & 14.2 & 42.9 \\
\hline \multirow[t]{2}{*}{ No } & 19 & 23.8 & 26.3 & 16.6 \\
\hline & \multicolumn{2}{|c|}{$(0.389)$} & \multicolumn{2}{|c|}{$(5.567)^{*}$} \\
\hline
\end{tabular}

Significance level $*<0.05 * *<0.01 * * *<0.001 ;$ (Pearson's chi-square value within brackets).

Table 4: Main source of fuel for cooking by wealth and caste

$\%$ of households

\begin{tabular}{lcccc}
\hline \multirow{2}{*}{ Fuel for cooking } & \multicolumn{2}{c}{ Wealth class } & \multicolumn{2}{c}{ Caste } \\
\cline { 2 - 5 } & Rich & Poor & 21.0 & Pahari \\
\hline Firewood & 32.5 & 33.3 & 13.2 & 47.4 \\
Kerosene & 17.5 & 16.7 & & 18.4 \\
\multicolumn{2}{l}{ a: Validation rule: Fisher's exact test (2-tailed significance $=0.714) ;($ Pearson's chi-square value within brackets). }
\end{tabular}




\section{Banko Janakari, Vol. 9, No. 2}

7) Sending children to school: These days, there is an increasing tendency to send children to schools. However, it is a complex decision process that involves a lot of factors (Foster, 1980; Shrestha, 1984; Kasaju et al.\} 1985). The economic calculations alone do not bring the children to schools. The increased opportunities of cash income, in fact, has resulted into early drop-outs of some children from schools as reported elsewhere in the literature (Hunt, 1978; Foster, 1980). Even the free education opportunity is not contributing to reduce the early drop-out of the children from schools.

It is widely claimed that with increased cash income, firewood will be either purchased as it will no longer be a free commodity or substituted with kerosene (Malla, 1993). However, it is observed that neither the rich households significantly differ from the poor regarding the use of fuel for cooking nor this difference is evident among the Brahmin and Pahari households (See Table 4).

\section{Reflections}

On one hand, the Government of Nepal is blamed for ignoring the commercial aspects of community forestry (Malla, 1993) while on the other, social forestry is criticised for omitting the subsistence need of the villagers (Monech et al., 1986). The argument for commercialisation of community forestry stems from an unfounded belief that under strong market influence villagers are interested in cash income and not on subsistence living. The assumption that under socioeconomic transformation the pressure on the forest decreases, is in fact, only a rosy depiction. The depiction that 'uncultivated marginal lands, reduction of livestock, stall feeding' subsequently reduces pressure from common forest (Malla, 1993) may not be true because some of the critical assumptions are unfounded.

This study also justifies Foster's (1980) question regarding the role of economic factors on children's education. Some poor Brabmin households are sending children to school despite the hardship, whereas some Pahari are retaining children in homes so that they can earn income through Betbans works. Hence, the decision regarding the schooling of children is not determined by the economic factors alone. The increased earning opportunity through Betbans work results into more dropouts of Pahari children from the school and even a free education opportunity is unable to retain them. This finding firmly agrees with observations elsewhere (Hunt, 1978; Foster, 1980) and is in contrast with Malla's (1993) expectation that an increased cash earning opportunity will place a larger number of children in the school.

It is also fallacious that under stronger market influence, the cultivation pattern shifts from the cereal to the cash crop. In principle, this study agrees that with increased cash income, people spend much on purchasing chemical fertilisers. However, saying that "a strong market orientation eventually leads to a reduction of pressure on the forest" is deceptive. It is assumed that under strong market influence, villagers may face acute labour-scarcity and that may encourage for shifting to cash crop (Malla, 1993). However, it is observed that the Parma is institutionalised to cope with labour scarcity during peak agriculture season or under severe cash-scarcity. The rich and poor households do not differ significantly regarding the use of Parma. Nevertheless, the Pahari households differ significantly from the rest. Hence, the existence of such institutions is culturally determined and the market influence may not be decisive. Such institutions may accommodate the scarcity of labour therefore, the so called 'new strategy' may not exist. Thus 'the rosy depiction' on reducing pressure from the forest (Malla, 1993) is just a mirage.

\section{Conclusion}

The so-called new strategy, supposedly adopted by the villagers in the wake of market influence, is hardly evident Community forest still plays a significant role in sustaining agriculture in the study area. The socio-economic transformations under increasing influence of the market not necessarily minimise the role of community forest as it still contributes substantially in sustaining the subsistence living. Many households still depend on community forest for basic forest products such as firewood, fodder, grasses, and leaf-litters; therefore commercialisation should be only at an amble pace.

Acknowledgements The study, a part of M Sc Thesis entitled "The impact of community forestry on income distribution" and submitted at Wageningen Agricultural University, was funded by a grant from the Netherlands Fellowship Programme with additional suppoit from the NARMSAP. The author would like to thank the Chairman of Kumari Ban FUG Chairman, Mr. B. M. Pahari and all the FUG members for their hospitality and co-operation.

\section{References}

Anonymous 1988. Master plan for forestry sector, main report, Ministry of Forest and Soil Conservation, HMG, Nepal. 


\section{Sharma}

APROSC 1980. Rapid Baseline Survey.

Agriculture Project Service Centre, Kathmandu, Nepal.

Banskota, M. C. 1989. Hill agriculture and the wider market economy: transformation processes and experience of the Bagmati in Nepal. ICIMOD Occasional Paper No. 10. International Centre for Integrated Mountain Development, Kathmandu, Nepal.

Bhatt, N. and Slayter, T. 1994. Land, livestock, and livelihoods: changing dynamics of gender, caste, and ethnicity in a Nepalese village. Human Ecology 22(4): 467-494.

Boserup, E. 1965 The conditions of agriculture growth: the economics of agrarian

change under population pressure. Allen and Unwin. London.

Foster, P. 1980. Education and social inequality in sub_saharan Africa. Journal of modem African studies 18: 201-236.

Hall, P. J. 1966. Von Thunen's isolated state. Oxford: Pergamon Press.

Hunt, D. M. 1978. Rural poverty and the viability of basic needs strategies. ILO, Ganeva.

Kasaju, P. and Manandhar, T. B. 1985. Impact of parents' literacy on school enrolments and

\section{Banko Janakari,Vol. 9, No. 2}

retention of children: the case of Nepal. IIEP, UNESCO; Paris; France

Malla, Y. B. 1993. Changing role of the forest resource market: an ignored dimension of community forestry. Banko Jankari 4(1):

Manandhar, P. K. 1980. Introduction to policy, legislation and programmes of community forestry development in Nepal. Community Forestry Development Project.

Kathmandu, Nepal.

Messerschmidt, D. A. 1981. Nogar and other traditional forms of cooperation in Nepal: significance for development. Human Organisation 40 (1): 40-47.

Moench, M. and Bandyopadhyaya, J. 1986. People- forest interaction: a neglected parameter in Himalayan forest managemet. Mountain Research and Development 6 (1): 3-16

Mortimore, M. and M. Tiffen 1995. Population and environment in time perspective: the Machakos storey. In Binns, T., (ed.) People and environment in Africa. John Wiley \& Sons Ltd.

Shrestha, G. M. 1984. Determinants of educational participation in rural Nepal. CERID/WEI project (main report) Kathmandu, Nepal. 